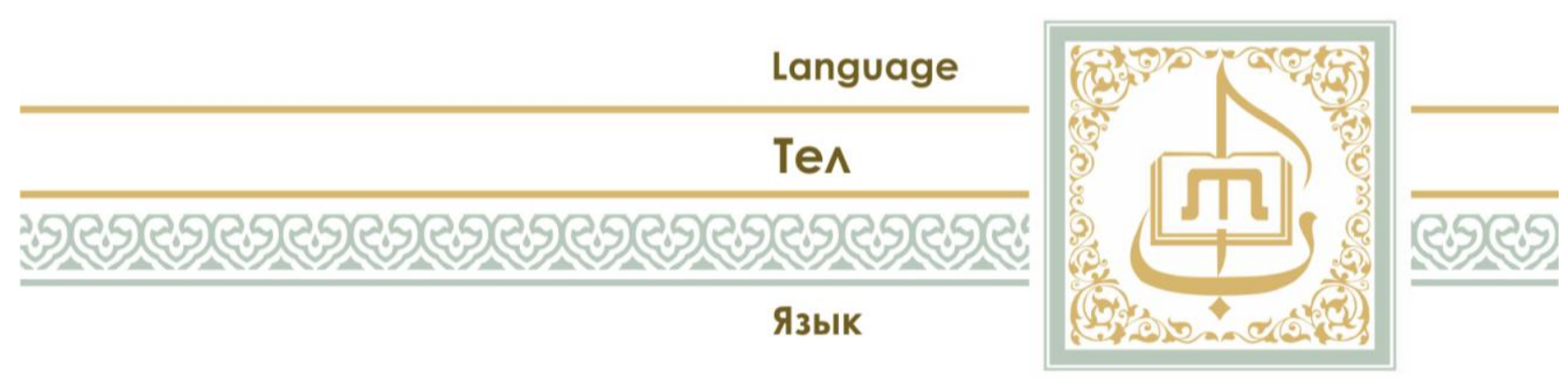

\title{
THE LANGUAGE OF TATAR ADVERTING: INFLUENCE OF CULTURAL VALUES
}

\author{
Gulnaz Nurkhametovna Fakhretdinova, \\ Kazan National Research Technological University, \\ 68 Karl Marx Str., Kazan, 420015, Russian Federation, \\ gulnaz_khamidull@mail.ru. \\ Gary D.Guadagnolo, \\ EAB, \\ 2445 M St. NW, Washington, DC 20037, USA, \\ garyguadagnolo@gmail.com.
}

\begin{abstract}
The paper analyzes the influence of Tatar cultural values on modern Tatar advertising. Cultural and national values are regarded as one of the effective ways of promoting goods and services. Tatar advertising is distinguished by national values that are inherent in native speakers and cultures, advertising takes into account the peculiarities of the mentality of the audience, moral norms and beliefs of the Tatar nation. Advertisements in the Tatar language often include elements of the socalled "national identity" in the advertising texts, which is expressed in the appeal to geographical indications, heroes of Tatar tales and poems, national holidays and cuisine, religious ceremonies, Tatar folk music as a background for radio advertising and promotion of Tatar performers through posters.
\end{abstract}

Key words: advertising text, Tatar language, cultural values, national identity, consumers, product promotion.

Being one of the most effective sources of information about goods and services, advertisement has become one of the most effective mechanisms of action on the human and it has a significant influence on people and their behavior. The advertisement also offers ready behavior samples introducing certain values and norms in a wider diapason [Vodopianova, p. 106]. People, living in different countries, perceive an advertising message differently, as it has elements of the ethnic picture of the world, national, and cultural traditions. Cultural variations might be a huge barrier if not taken into consideration and it is important to understand that cultures have different values and attitudes [Iohannessen, p. 8]. Advertising is an indicator of the real language situation and functionality of the Tatar language so the study of the linguistic features of the Tatar advertising texts makes it possible to identify specific ways of using language techniques in 
order to provide a speech impact of advertising texts on a potential consumer.

Tatar advertising enjoys its current revival and active development, which is primarily due to socio-economic circumstances, such as business growth, competition in the market, which leads to the desire of producers to distinguish their products from a number of similar ones. There are other important factors, contributing to the formation of Tatar advertising. First of all, strengthening the status of the Tatar language as the state language by adopting the Law of "On the State Languages of the of the Republic of Tatarstan" in July 1992 and the State Program of the Republic of Tatarstan for the Preservation, Study and Development of the State Languages of the Republic of Tatarstan in July 1994. The mentioned law and program provide for the preservation, study and dissemination of the official languages of the Republic of Tatarstan, as well as determine ways to improve the status of the Tatar language in various spheres of public life. Today, we observe the growing interest in the native language and culture, as well as the desire to expand the social functions of the Tatar language.

Secondly, every day dozens of Tatar commercials stream in the Tatar television and radio, advertising texts are printed on the pages of Tatar periodicals and Internet resources. Over the last decades "Yanga Gasyr" ("New Century") State Television and Radio Company was created (which later was renamed to "Bulgar Radiosi"); a number of commercial radio stations such as "Kuray", "Tatar Radiosi", "Kungel”, "Azatlyk", "Tartip" (later joined "Bulgar Radiosi"), aimed at a Tatar-speaking audience, started broadcasting in the Tatar language. There are a lot of private Tatar newspapers, magazines and regional newspapers, whose incomes often completely depend on advertising.

Under the influence of the above factors, modern Tatar advertising began to change in volume and quality: advertisers try to take into account the consumer's attitude to the advertised product; the development of social networks has created new types of advertising. The linguistic arrangement of advertising texts, which are created according to the tastes, social orientation, age and gender of a potential client, play an important role in the process of informing and influencing the audience.

S. G. Ter-Minasova compares language to a mirror of culture, which reflects the real world surrounding a person, his/her living conditions, so- cial identity and mentality of the people, national character, lifestyle, traditions, customs, morality, their system of values and vision of the world. The researcher believes that the language stores cultural values in vocabulary, grammar, idioms, proverbs, sayings, in folklore, in fiction and non-fiction, written and oral forms [Ter-Minasova, p. 14]. The relationship between language and national culture is analyzed by R. R. Zamaletdinov, who noticed that ethnic mentality in language is actualized in key concepts and its study allows looking into the core of the national culture [Zamaletdinov, p. 125].

The specificity of Tatar advertisements is that they are aimed at a specific audience that speaks the Tatar language and lives in the Republic of Tatarstan or in nearby regions. According to A. A. Gafurova, Tatar advertising includes the socalled national color, expressed by linguistic and extra linguistic means. The researcher points to the national and cultural components as distinctive features of national advertising [Gafurova, p. 49]. As E. K. Kuzmina notes, the perception of advertising in each country has been historically shaped due to its cultural and national traditions. The national culture and values of people influence the perception of advertised products [Kuzmina, $\mathrm{p}$. 43].

The universal values of the Tatars are quite similar to the modern global values, which include the presence of a good high-paying job, cars, real estate, and prestigious education. The desire to be wealthy and have a high position in society are reflected in the texts of Tatar advertising, and it offers not just a certain product, information is often presented in such a way that a certain lifestyle is formed: "Zapadnaya Orekhovka" kottedzh bistase - sezneng tormyshka ashkan hyalygyz! Nindi oylar?! A nindi tabigat?! Saf hava, shahar ungaylyklary. "Unistroy" kompaniyase 4 million 500 meng sumnan alyp Evropa darazhesendage azer yortlar takdim ita. "Unistroy" - kilachakka yanga omet belan! - The cottage settlement "Western Orehovka" is your dream that has come true! What are the houses like?! Beautiful nature! Clean air, urban conditions. The company "Unistroy" offers finished houses of the European level from 4 million 500 thousand. "Unistroy" is with hope for the future (Tatar Radiosi, 2011, March).

Tatar advertising is distinguished by national values that are inherent in native speakers and cultures, advertising takes into account the peculiarities of the mentality of the audience, moral norms and ideals characteristic of the Tatar 
nation. A. A. Gafurova thinks that by using elements of the recipient's culture, advertisers manipulate the minds of the recipients of the message, playing on feelings of nostalgia, trust, and patriotism [Gafurova, p. 44]. The presence of a patriotism motive in Tatar advertising underlines the fact that the goods are produced in Tatarstan and it is the guarantor of reliability and confidence for the consumer, because the buyer is likely to make a choice in favor of local producers: "Chistay it kombinaty" kup tordage kazylyklar takdim ita. Tatarstanda usterelgan siyer, dungyz itennan zhiteshterelgan kazylyklar tam, syjfaty belan aerylyp tora. "Chistay it kombinaty" 70 yel sezneng belan eshli. - "Chistopol meat factory" offers various kinds of smoked meats. High-quality sausages made from beef and pork are produced in Tatarstan. "Chistopol meat factory" has worked for 70 years (Tatar Radiosi, 2008, March).

When it comes to geographical indications the advertiser focuses on the words Kazan, Tatarstan, settlements of Tatarstan and pronouns emphasize the territorial affiliation of the manufacturer: "uzebezneng" - "own", "uzebeda" - "here", "bezneke" - "our" and their variations: - Aniem minga kichke akiyat soylache! - Yashagan di ber gaila. Berkaychan da avyrmagannar, harvakyt taza-sau bulgannar, chonki Tatarstanda usterelgan terlek itennan azerlangan siyfatly, tamle, arzan bayale it rizyklary ashap torgannar, di. - A alar any kaydan algannar? - Rodina uramy 33 nche yortta urnashkan "Altyn bozau" ham shahardage barlyk azyk-tolek kibetlarennan. - Bu bit bezneng gaila turynda. - Aye, balam. Bahetle gaila "Kazan it kombinaty" produktsiyasen sayliy. - Mom, can you tell me a bedtime story? - Once upon a time there was one family. They have never been ill, they have always been healthy, as they always have high-quality, tasty meat products produced in Tatarstan at low prices. - Where do they buy them? - In "Altyn Bozau" store, which is located on 33 Rodina Street and these products can be bought in all grocery stores of the city. This is about our family. - Yes, my baby. A happy family chooses the products of the "Kazan meat factory" (Tatar Radiosi, 2011, April).

Tatar advertising texts reflect the places of great importance in the history of Tatarstan and the formation of the Tatar people, for example the city of Bilyar. As researchers note, the placename "Bilyar" is considered to have a sacred significance and to be a national and cultural component - a holy site. The nomination is motivated by the fame of this placename, its national and cultural component, and its bright historical and cultural connotation [Zamaletdinov, Galiullina, p. 84]. Danlykly Bilyar shahare yanynda legendalar belan urelgan tamle ham komeshtay chista suly Izge Bilyar chishmase bar! Tabigat uze baetkan, shifaly uzenchaleklarga iya "Bilyar Su”y hazer sezneng oegezda da! "Bilyar Su” - babalarybyz ochkan su! - Near the famous city of Bilyar there is a spring - Saint Bilyar, shrouded in legends, where the water is tasty and as pure as silver! Filled with nature itself, healthy "Bilyar Su" is now in your home. "Bilyar Su" is the water that our ancestorsused to drink! (Tatar Radiosi, 2008, June).

Advertisers often include elements of the socalled "national identity" in the advertising texts, which is expressed in the appeal to the elements of ethnic culture, national heroes, traditions, and music. In the book "The Software of Mind", researchers emphasize four general manifestations of culture, and among them: symbols, rituals, heroes and values, which, in their turn, can be taken for the basis when constructing advertising companies [Hofstede, Hofstede, Minkov]

The well-known verses from Gabdulla Tukay's works were converted by advertisers and succefully used in the advertising text: Nak Kazan artynda bardyr shap kunakhana - "Dubai" dilar; boten sharty, tabigate harkemga ungai dilar! Bu hozurlykka kilep, billiard uyna, siylan, shayart, muncha kerep, yal itarseng hal zhyep kukka karap! "Dubai" kunakhana kompleksy! - There is a hotel near Kazan called "Dubai", all the conditions, natural environment will please everyone! Come to this blissful place, play billiards, have fun, go to the banya and have a rest! Hotel complex "Dubai" (Tatar Radiosi, 2009, June). In this example an excerpt was taken from Tukay's fairy tale "Shurale" which begins with the words "Nak Kazan artynda bardyr ber avyl Kyrlay dilar ..." - There is a village next to Kazan under the name Kyrlay... This is a fairly effective technique, since allusions (appeal to well-known literary works) increase the impact of advertising and contribute to its memorization. Each time listening to this commercial, the recipients associate it with Gabdulla Tukay and his famous tale "Shurale", which causes only positive emotions.

Hospitality is part of Tatar national identity, the guest in the Tatar house is always welcomed and treated as the dearest person, he/she takes pride of place at the table. The traditional treats of the Tatars are tutyrgan tavyk (chicken stuffed with 
egg), tokmach ashy (noodle soup), balesh (a big pie stuffed with potatoes and meat), olesh (a little pie with chicken and potatoes), kystybiy (a thin bread filled with mashed potatoes), gubadiya (a sweet multiple layer pie), bavyrsak and chak-chak (sweets made of dough with honey), talkyshkaleve (honey and sugar candy mixture) and others. Advertisers often emphasize the observing centuries-old traditions in cooking, refinement, originality of Tatar cuisine and hospitality of the Tatar people: "Bilyar" restorannar cheltare: arzan bayaga tamle rizyklar! Tatar halkynyng milli ashlary - olesh, ochpochmak, kystybiy, talkysh kaleve, tatly, gobadiya sezne bitaraf kaldyrmas! Sezne tamlap asharga ham matur kich uzdyryrga Kazan uzagenda urnashkan restorannarnyng bersena chakyrabyz. - Restaurants chain "Bilyar": delicious food at low prices! Tatar national dishes such as olesh, ochpochmak, kystybiy, talkysh kaleve, tatly, gobadiya will not leave you indifferent! We invite you to enjoy a delicious meal and spend a wonderful evening in one of the restaurants located in the center of Kazan (Tatarstan, 2007, November).

Religion has been a significant factor influencing thinking and national identity of Tatar people over the centuries. Since the adoption of Islam in 922, religion has played a crucial role in shaping the worldview and mentality for the Tatar's ancestors; it has become one of the cultural and ideological bases. Every believing Muslim must observe the rites of Islam, which include wearing appropriate clothing, five-time prayer, fasting, celebration of Uraza-bayram and Kurbanbayram, sacrifice, zakat (distribution of alms) and hajj. A religious motive is very common in Tatar advertising, along with commercial advertising offering Muslim clothing, halal products there is also a social advertisement calling to attend mosques, to listen to sermons or announcing the opening of mosques: Hormatle din kardashlarebez! Izge Ramazan aenda sezne har konne "Bolgar" restoranyna Iftar ashyna chakyrybyz. - Dear Muslims! Every day in the holy month of Ramadan we invite you to Iftar in the restaurant "Bolgar" (Bolgar radiosi, 2018, May).

Advertisers need to be creative and deliver memorable messages in order to gain attention and persuade potential consumers to use the product. Besides language means advertisers use nonverbal methods to emphasize the regular language. One of the most popular non-linguistic techniques in radio advertising is the use of Tatar music. National motives help to create an advertising image and national character. Most often, Tatar national music acts as a background in advertising restaurants and cafes offering Tatar dishes or souvenir shops selling local products. For example, the Tatar cuisine chain "Tubetey" always uses Tatar folk dance motifs to advertise its cafes: Igtibar! Chehiyaga bushlay baryrga telisengme? Zamancha smartfon yaki bashka bulaklar otar idengme? "Tubatay"ga ashyk! Bezneng "Tubatay" tuklanu noktalarynda, "Lukoil" avtomobil yagulyk stantsiyalarenda urnashkan kafelarybyzda 300 sumga rizyklarybyzdan avyz it, "Bolgar radiosi" kodyn ayt ham zhitmesh bulakneng berse - sineke - Attention! Do you want to go to the Czech Republic for free? Do you want to win a modern smartphone or other prizes? Hurry up to "Tubetey"! Buy anything for 300 rubles at our Tubetey fast-food restaurants or cafes located at Lukoil gas stations, say the codeword "Bolgar radiosi" and one of the seventy prizes is yours (Bolgar radiosi, 2017, October).

Tatar advertising focuses on the Tatar-speaking audience, which is interested in Tatar culture, attends concerts and theaters and listens to Tatar music. As N. V. Gordeeva notes, the goods and services related to audio information (concerts, releases of performers' albums, musical events) have a great advantage when placed on radio [Gordeeva, p. 44]. Our factual material shows that Tatar advertisers also prefer radio while announcing upcoming entertainment events, as this attracts the attention of radio listeners. Commercials with information about the concerts or any entertainment events with the participation of Tatar artists always contain Tatar music in the background (it can be an excerpt from the famous song). For example, in the advertisement of the famous singer Elvina we hear her song in the background: Kabatlanmas, harvakyt soklandyrgych Elvina "Zhyrliymyn Soyudan" dip atalgan yanga izhat programmasyna chakyra. Berenche tapkyr - musykal spektakl monolog. The unique, always delightful Elvina invites you to her new original program "I sing for love". The first time musical performance-monologue (Tatar Radiosi, 2018, November).

An appeal to national and cultural values enhances the effect of advertising and is an effective way of promoting goods and services in the local market. Potential consumers who speak Tatar or consider themselves to be ethnic Tatars will be interested in the information presented in their native language. After analyzing the actual material of advertising texts, we can conclude that 
the main motive inherent in advertising in general, which dominates in the texts of Tatar advertising is a desire for a dream, well-being, and success.

\section{References}

Gafurova, A. A. (2012). Spetsifika funktsionirovaniya onomasticheskoy leksiki $v$ tatarskih $i$ angloyazychnyh reklamnyh tekstah: diss. ... kand. filol. nauk [The Specifics of Onomastic Vocabulary Functions in Tatar and English Advertising Texts: Ph.D. Thesis]. 246 p. Kazan. (In Russian)

Gordeeva, N. V. (2012). Funktsionalno-tvorcheskie osobennosti tekstov radioreklamy (russkoyazychnoe FM-veschanie Kazani: diss. ... kand. filol. nauk [Functional and Creative Features of Radio Advertising Texts (Russian-language FM broadcast of Kazan): Ph.D. Thesis]. 197 p. Kazan. (In Russian)

Hofstede, G., Hofstede, G. J., Mnikov, M. (2010). Cultures and Organizations: Software of the Mind. 558 p. New York, Mc Graw Hill, New York (In English)

Iohannessen, K. S. (2010). The Language of Advertising: Powerful, Innovative and Environmental? New perspectives on sustainability. No 2. pp. 6-27. (In English)
Kuzmina, E. K. (2012). Yazykovaia modeliruemost reklamnyh tekstov (na materiale russkogo, frantsuzskogo i angliyskogo iazykov): diss. ... kand. filol. nauk [Language Modeling of Advertising Texts (based on Russian, French and English): Ph.D. Thesis]. 195 p. Kazan. (In Russian)

Ter-Minasova, S. G. (2008). Iazyk i mezhkulturnaia kommunikatsiia [Language and Cross-cultural Communication]. 264 p. Moscow, Slovo. (In Russian)

Vodopyanova, N. A. (2008). Advertisement in System of Intercultural Communications. European Journal of Natural History. No 3. pp 106-110. (In English)

Zamaletdinov, R. R. (2004). Tatarskaia Kultura $v$ iazykovom otrazhenii [Tatar Culture Mirrored in Language]. 239 p. Moscow, Vlados, Kazan, Magarif. (In Russian)

Zamaletdinov, R. R., Galiullina G. R. (2018). Natsionalno-kulturnyi fon nekotoryh tatarskih imen sobstvennyh [National-Cultural Background of Some Tatar Proper Names]. Tyurkskaia onomastika ot istokov do sovremennosti: materialy Mezhdunarodnoi nauchnoprakticheskoi konferentsii. Kazak, izd-vo Kazan. un-ta. pp. 83-86. (In Russian)

\title{
ТАТАР РЕКЛАМАСЫ ТЕЛЕ: МӘДӘНИ ХӘЗИНӘЛӘРНЕН ЧАГЫЛЫШЫ
}

\author{
Гөлназ Нурхамәтовна Фәхретдинова, \\ Казан милли тикшеренү технология университеты, \\ Россия, 420015, Казан ш., Карл Маркс урамы, 68 нче йорт, \\ gulnaz_khamidull@mail.ru. \\ Гари Г. Гуадагноло, \\ Чапел Хиллдагы Төньяк Каролина университеты, \\ АКШ, 20037, Вашингтон, Колумбия төбәге, М ур., ТК, 2445 йорт, \\ ЕАБ, \\ garyguadagnolo@gmail.com.
}

\begin{abstract}
Мәкаләдә татар мәдәни хәзинәләренең хәзерге татар рекламасына йогынтысы анализлана. Мәдәни һәм милли кыйммәтләр товарларны һәм сервис хезмәтләрен алга этәрүнең нәтижәле ысулларының берсе буларак карала. Татар рекламасы тел һәм мәдәниятләргә хас милли кыйммәтләр белән аерылып тора, реклама аудиториянең менталитет үзенчәлекләрен, әхлакый нормаларны həм татар милләтенең үзенчәлекләрен исәпкә ала. Татар реклама текстлары еш кына «милли үзаң» элементларын үз эченә ала, бу исә географик атамаларга, татар әкиятләренә həм шигырьләренә, милли бәйрәмнәргә һәм ризыкларга, дини йолаларга, радиорекламалар өчен фон сыйфатында татар халык музыкасына мөрәжәгать иткәндә һәм афиша ярдәмендә татар башкаручыларын пропагандалауда чагыла.
\end{abstract}

Төп төшенчәләр: реклама тексты, татар теле, милли хәзинәләр, милли үзаң, кулланучылар, товарларны тәкъдим итү.

Товарлар һәм хезмәтләр турында мәгълүматның иң нәтижәле чыганакларыннан берсе буларак, бүгенге заманда реклама кешегә йогынты ясауның иң нәтижәле механизмнарының берсенә әверелде, ул кешеләр һәм аларның Yз-үзләрен тотышына сизелерлек 
йогынты ясый. Реклама, шулай ук үз-үзеңне тотуның билгеле бер кыйммәтләрне һәм нормаларны киң диапазонда кертә торган әзер үрнәкләрен тәкъдим итә [Водопянова, б. 106]. Төрле илләрдә яшәүче кешеләр дөньяның этник картинасы, милли һәм мәдәни традиция элементларын Үз эченә алган реклама хәбәрләрен төрлечә кабул итәләр. Мәдәни аермалар тагын да зуррак барьер тудырырга мөмкин, шуңа күрә мәдәниятләргә төрле кыйммәтләр хас булуына игътибар итү һәм аңлау мөһим [Йоханессен, б. 8]. Реклама татар теленең реаль вәзгыяте һәм функциональ мөмкинлекләре күрсәткече булып тора, шунлыктан татар реклама текстларының тел үзенчәлекләрен өйрәнү потенциаль кулланучыга тәэсир иткән реклама текстларының телнең аерым ысулларын куллануны ачыкларга мөмкинлек бирә.

Бүгенге көндә татар телендәге рекламаның яңарышы hәм актив үсеше күзәтелә, бу, беренче чиратта, бизнес үсеше, базарда көндәшлек кебек социаль-икътисади шартларга бәйле, ә ул, үз чиратында, житештерүчеләрнең Y3 продукциясен башкалардан аеру ихтыярына китерә. Татар рекламасын формалаштыруга ярдәм иткән башка мөһим факторлар да бар. Беренчедән, 1992 нче елның июлендәге «Татарстан Республикасының дәүләт телләре турында» законын hәм 1994 нче елның июлендә кабул ителгән «Татарстан Республикасының дәүләт телләрен саклау, өйрәнү һәм үстеру» дәүләт программасын кабул итү татар теле статусын дәүләт теле буларак ныгытты. Әлеге закон һəм программа Татарстан Республикасының рәсми телләрен саклау, өйрәнү һәм үстерүне, шулай ук ижтимагый тормышның төрле өлкәләрендә татар теленең статусын күтәрү юлларын билгеләүне күздә тота. Бүген без туган тел һәм мәдәнияткә кызыксыну артуын, шулай ук татар теленең социаль функцияләре киңәюен күзәтәбез.

Икенчедән, көн саен татар телевидениесендә һәм радиода дистәләрчә татар реклама роликлары трансляцияләнә, реклама текстлары татар вакытлы матбугатында һәм интернетта басыла. Соңгы ун елда «Яңа гасыр» («Новый Век») дәүләт телерадиокомпаниясе (соңрак «Болгар радиосы»на үзгәртелә), «Курай», «Татар радиосы», «Күңел», «Азатлык», «Тәртип» (соңрак «Болгар радиосы»на кушыла) кебек кайбер коммерция радиостанцияләре татарча сөйләшә торган аудитория өчен эшли башлады. Күп кенә шәхси татар газеталары һәм журналлары, жирле газеталарының кереме еш кына тулысынча рекламага бәйле.

Хәзерге татар рекламасы алда санап үтелгән факторларның йогынтысында күләме һәм сыйфаты ягыннан үзгәрә башлый: реклама бирүчеләр кулланучының реклама продуктына мөнәсәбәтен исәпкә алырга тырыша; социаль челтәрләрнең үсеше белән рекламаның яңа төрләре барлыкка килә. Мәгълүмат бирү һәм адресатка йогынты ясау процессында реклама текстларының тел ягыннан бизәлеше мөһим роль уйный, алар кулланучыларның зәвыгын, социаль ориентациясен, яшь һәм гендер үзенчәлекләрен исәпкә алып оештырыла.

С.Г. Тер-Минасова телне мәдәният көзгесе дип атый, анда кешенең әйләнә-тирә дөньясы, аның тормыш шартлары, ижтимагый үзаңы, халыкның менталитеты, милли характеры, яшәү рәвеше, гореф-гадәтләре, мораль кыйммәтләр системасы, дөньяны күзаллавы чагылыш таба. Тел мәдәни кыйммәтләрне лексикада, грамматикада, идиомаларда, мәкальәйтемнәрдә, фольклорда, фәнни һәм матур әдәбиятта, язма һәм әйтмә формаларда саклый, дип саный тикшерүче [Тер-Минасова, б. 14]. Тел һәм милли мәдәниятнең үзара бәйләнешенә P.P. Жамалетдинов мөрәжәгать итә, ул этник менталитетның телдә актуальләшүен һәм аның милли мәдәният чыганагы булуын билгеләп үтә [Замалетдинов, б. 125].

Татар рекламасы Татарстан Республикасында һәм күрше төбәкләрдә яшәүче татар телле аудиториягә юнәлдерелгән. А. Гафурова билгеләп Үткәнчә, «татар рекламасы лингвистик hәм экстралингвистик чаралар белән белдерелгән милли колоритны кертергә омтыла». Автор хезмәтендә милли-мәдәни компонентны милли рекламаның үзенчәлеге буларак билгели [Гафурова, б. 49]. Е. К. Кузьмина билгеләп үткәнчә, «һәр илдә рекламаны кабул итү тарихи яктан формалаша, шул ук вакытта ул мәдәни һәм милли традицияләргә нигезләнә. Милли мәдәният һәм кешеләрнең кыйммәтләре реклама продукциясен кабул итүгә дә йогынты ясый» [Кузьмина, б. 43].

Хәзерге вакытта татарларның дөньяви кыйммәтләре башка халыкларныкы белән охшаш һәм аларга яхшы хезмәт хакы түләнә торган эш, автомашиналар, күчемсез милек, дәрәжәле югары белем керә. Бай, мөлкәтле булу, жәмгыятьтә югары урын биләү теләге татар рекламаларында ачык күренə. Рекламада билгеле бер товар гына түгел, мәгълүмат аша билгеле бер тормыш стиле формалаштырыла: 
«Западная Ореховка» коттедж бистәсе сезнең тормышка ашкан хыялыгыз! Нинди өйләр?! Ә нинди табигать?! Саф haва, шәһәр уцайлыклары. «Унистрой» компаниясе 4 миллион 500 мең сумнан алып Европа дәрәжсасендәге әзер йортлар тәкъдим итә. «Унистрой» - киләчәккә яңа өмет белән! (Татар радиосы, 2011, март).

Татар рекламасын тел һәм мәдәнияткә хас милли кыйммәтләр аерып тора, реклама бирүчеләр аудиториянең менталитет үзенчәлекләрен, әхлакый нормаларны һәм татар милләтенә хас идеалларны исәпкә ала. А. А. Гафурова билгеләп үткәнчә, «реклама адресатының мәдәният элементларын кулланып, рекламаны оештыручылар реципиентның ностальгия, ышаныч, ватанпәрвәрлек хисләре ярдәмендә манипуляциялиләр» [Гафурова, б. 44]. Татар рекламасында ватанпәрвәрлек мотивы, товарның нәкъ менә Татарстанда житештерелүе кулланучы өчен ышаныч гарантиясе булып тора, чөнки сатып алучы жирле житештерүчеләр файдасына өстенлек бирергә мөмкин: "Чистай ит комбинатьл" күп төрдәге казыльклар тәкъдим итә. Татарстанда үстерелгән сыер, дуңұгыз итеннән жситештерелгән казылькллар тәм, сыйфаты белән аерылып тора. "Чистай ит комбинаты» 70 ел сезнең өчен эшли (Татар радиосы, 2008, март).

Географик күрсәткечләр турында сүз барганда, реклама бирүче Казан, Татарстан, Татарстанның торак пунктлары һәм жирле продукция житештерүченең территориаль үзенчәлеген ассызыклый: «үзебезнең», "Үзебезда», «безнеке» һәм аларның төрләре: Әнием, миңа кичке әкият сөйләче! - Яшәгән ди бер гаиль. Беркайчан да авырмаганнар, һәрвакыт таза-сау булганнар, чөнки Татарстанда устерелгән терлек итеннән әзерләнгән сыйфатлы, тәмле, арзан бәяле ит ризыклары ашап торганнар, ди. - Ә алар аньл кайдан алганнар? - Родина урамы 33 нче йортта урнашкан "Алтын бозау» һәм шәһәрдаге барльк азык-төлек кибетләреннән. - Бу бит безнең гаилә турында. - Әйе, балам. Бәхетле гаиль "Казан ит комбинаты» продукциясен сайлый (Татар радиосы, 2011, апрель).

Татар реклама текстларында Татарстан тарихында зур әһәмияткә ия булган урыннар, мәсәлән, Биләр шәһәре чагылыш таба. Тикшерүчеләр билгеләп үткәнчә, Биләр милли мәдәни әһәмияткә ия булган изге урын итеп санала. Номинация бу исемнең житәрлек дәрәжәдә танылуына, милли-мәдәни байлыкка hәм тарихи-мәдәни коннотациягә нигезләнгән [Жамалетдинов, Галиуллина, б. 84]. Данлыклы Биләр шәһәре янында легендалар белән үрелгән тәмле һәм көмештай чиста суль Изге Биләр чишмдсе бар! Табигать үзе баеткан, иифаль үзенчәлекләрга ия “Биләр $\boldsymbol{C}$ ”" хи хәзер сезнең өегездә дә! «Биләр Су» - бабаларыбыз эчкән cy! (Татар радиосы, 2008, июнь).

Реклама бирүчеләр еш кына реклама текстларына «милли үзаң» элементларын кертә, бу исә этник мәдәнияткә, милли геройларга, гореф-гадәтләргә, музыкага мөрәжәгать итүдә чагыла. «Управление разумом» хезмәтендә тикшерүчеләр дүрт гомуми мәдәният чагылышын бирә һәм алар арасына реклама компаниясенә нигез булып торган символлар, ритуаллар, геройлар hәм кыйммәтләр кертелә [Hofstede, Hofstede, Minkov].

Габдулла Тукайның танылган шигырьләре реклама бирүчеләр тарафыннан үзгәртелеп, реклама текстында уңышлы файдаланыла: Нәкъ Казан артында бардыр шәп кунакханә «Дубай» диләр, бөтен шарты, табигате һәркемгә уңай диләр! Бу хозурльккка килеп, бильярд уйна, сыйлан, шаярт, мунча кереп, ял итәрсең хәл жсыеп күккә карап! "Дубай» кунакханә комплексы! (Татар радиосы, 2009, июнь). Бу мисалда Тукайның «Шүрәле» поэмасыннан өзек алына, билгеле булганча, ул «Нәкъ Казан артында бардыр бер авыл Кырлай диләр...» дигән сүзләр белән башланып китә. Бу - шактый эффектив ысул, чөнки аллюзия (танылган әдәби әсәрләргә мөрәжәгать итү) рекламаның тәэсирен көчәйтә һәм аны истә калдырырга ярдәм итә. Әлеге рекламаны тыңлаганда, кеше аны Габдулла Тукай һәм аның атаклы «Шүрәле»се белән бәйли.

Кунакчыллык - татар милли үзенчәлегенең бер өлеше булып тора, татар йортында кунакны гел иң кадерле кеше буларак каршылыйлар, аны табын артында түргә утырталар. Татарларның милли сый-нигъмәтләре рәтенә тутырган тавык, токмач ашы, бәлеш, өлеш, кыстыбый, гөбәдия, бавырсак, чәк-чәк, талкышкәләвә һәм башкалар керә. Реклама бирүчеләр ризык әзерләүнең һәм кунак кабул итүнең күп гасырлы традицияләрен, татар ашларының үзенчәлеген еш ассызыклый: «Биләр» рестораннар челтәре: арзан бәягә тәмле ризыклар! Татар халкының милли ашлары өлеш, өчпочмак, кыстыбый, талкыш кәләвә, татлы, гөбддия - сезне битараф калдырмас! Сезне тәмләп ашарга һәм матур кич 
уздырырга Казан Узәгендә урнашкан рестораннарныңң берсенә чакырабыз

(Татарстан, 2007, ноябрь).

Дин гасырлар дәвамында татар халкының милли үзенчәлегенә һәм фикерләвенә йогынты ясаучы әһәмиятле фактор булып тора. 922 елда Ислам динен кабул иткәннән соң, дин дөньяга караш формалаштыруда хәлиткеч роль уйный, мәдәни һәм идеологик нигезләрнең берсенә әверелә. Диндәге кеше Ислам йолаларын үтәргә, ягъни тиешле кием кияргә, биш тапкыр намаз укырга, ураза тотарга, Корбан бәйрәме уздырырга, Корбан чалырга, зәкят бирергә (хәер таратырга) hәм хажга барырга тиеш. Татар рекламасында дини мотив бик киң таралган, алар арасында мәчетләргә барырга, вәгазьләр тыңларга өнди торган яки мәчет ачу турында игълан иткән социаль реклама да бар: Хөрмәтле дин кардәиләребез! Изге Рамазан аенда сезне һәр көнне «Болгар» рестораньна Ифтар ашына чакырабыз (Болгар радиосы, 2018, май).

Реклама бирүчеләргә, игътибарны жәлеп итү һәм потенциаль кулланучыларны продукттан файдаланырга күндерү өчен, креатив булу һәм истә калырлык хәбәрләр төзү бик мөһим. Тел чараларыннан тыш, реклама бирүчеләр телдән тыш (вербаль булмаган) алымнарны да куллана. Радиорекламада, тел чараларыннан тыш, татар музыкасын куллану популяр. Милли мотивлар реклама образын һәм милли характерны күрсәтергә ярдәм итә. Татар милли музыкасы, барыннан да бигрәк, жирле азыктөлек белән сәүдә итүче ресторан һәм кафе рекламасында фон булып тора. Мәсәлән, «Түбәтәй» татар ашлары челтәре татар халык бию мотивларын Ү3 кафеларын рекламалау өчен һәрвакыт куллана: Игътибар! Чехиягə бушлай барырга телисенме? Заманча смартфон яки башка бүләкләр отар иденуме? «Түбәтәй»гә ашык! Безнен «Түбәтәй» тиз туклану нокталарында, «Лукойл» автомобиль ягульк станциялорендә урнашкан кафеларыбызда өч йөз сумга ризыклардан авыз ит, «Болгар радиосы» кодын әйт һәм жсчтмеш бүләкнең берсе - синеке! (Болгар радиосы, 2017, октябрь)

Татар рекламасы татар мәдәнияте белән кызыксынган, концертлар һәм театрларга йөри, татар музыкасын тыңлый торган татар телле аудиториягә юнәлтелгән. Н.В. Гордеева билгеләп үткәнчә, аудиоинформация белән бәйле товарлар һәм халыкка хезмәт күрсәтүләр (концертлар, башкаручылар альбомнарының релизлары, музыкаль чаралар), радиода урнаштырган очракта, зур өстенлеккә ия [Гордеева, б. 44]. Безнең фактик материал шуны күрсәтә: татар рекламалаучылары күңел ачу чараларын рекламалаганда радиостанцияләргә өстенлек бирәләр. Татар артистлары катнашындагы концерт яки күңел ачу чаралары турындагы реклама роликлары һәрвакыт фон режимында татар музыкасы ярдәмендә бирелә (мәсәлән, танылган жырдан өзек). Әйтик, танылган жырчы Эльвина концерты рекламасында арткы планда аның жыры ишетәлә: Кабатланмас, һәрвакыт сокландыргыч Эльвина «Жьрльиймын сөюдән» дип аталган яна ижсат программасына чакыра. Беренче тапкыр - музыкаль спектакль-монолог (Татар радиосы, 2018, ноябрь).

Милли һәм мәдәни кыйммәтләргә мөрәжәгать итү рекламаның йогынтысын көчәйтә һәм товарлар сату һәм хезмәт күрсәтүне алга этәрүнең нәтижәле ысулы булып тора. Татар телендә сөйләшкән яки үзен этник татар дип санаган потенциаль кулланучыга туган телдә тәкъдим ителгән мәгълүмат кызыклы булачак. Жыелган фактик материалга таянып, татар реклама текстларында өстенлек иткән төп мотив хыялга, иминлеккә һәм уңышка омтылу дигән нәтижә ясарга мөмкин.

\section{Әдәбият}

Гафурова А. А. Специфика функционирования ономастической лексики в татарских и английских рекламных текстах: дисс....канд.филол.наук. Казань, 2012. 246 c.

Гордеева Н. В. Функционально-творческие особенности текстов радиорекламы (русскоязычное вещание Казани): дисс. ... канд. филол. наук. Казань, 2012. 197 с.

Замалетдинов Р. Р. Татарская культура в языковом отражении. Москва: Владос, Казань, Магариф, 2004. 239 c.

Замалетдинов Р. Р., Галиуллина Г. Р. Национально-культурный фон некоторых татарских имён собственных. Тюркская ономастика от истоков до современности: материалы Международной научнопрактической конференции. Казань: изд-во Казан. ун-та, 2018. С. 83-86.

Кузьмина Е. К. Языковая моделируемость рекламных текстов (на материале русского, французского и английского языков): дисс. ... канд. филол. наук. Казань, 2012. 195 с.

Тер-Минасова С. Г. Язык и межкультурная коммуникация. Москва: Слово, 2008. 264 р.

Hofstede, G., Hofstede, G. J., Mnikov M. Cultures and organizations: Software of the Mind. New York, Mc Graw Hill, New York, 2010. 558 p. 
Johannessen $K$. S. The language of advertising: powerful, innovative and environmental? New perspectives on sustainability. 2010. No 2. pp. 6-27.
Vodopianova N. A. Advertisement in system of intercultural communications. European Journal of Natural History, 2008. No 3. pp 106-110.

\title{
ЯЗЫК ТАТАРСКОЙ РЕКЛАМЫ: ОТРАЖЕНИЕ КУЛЬТУРНЫХ ЦЕННОСТЕЙ
}

\author{
Гульназ Нурмухаметовна Фахретдинова, \\ Казанский национальный исследовательский технологический университет, \\ Россия, 420015, Казань, ул. Карла Маркса, д. 68, \\ gulnaz_khamidull@mail.ru.
}

Гари Д. Гуадагноло, Университет Северной Каролины в Чапел Хилл, США, 20037, Вашингтон, Округ Колумбии, ЕАБ, ул. М С3, д. 2445, garyguadagnolo@gmail.com.

\begin{abstract}
В статье анализируется влияние татарских культурных ценностей на современную татарскую рекламу. Культурные и национальные ценности рассматриваются как один из эффективных способов продвижения товаров и услуг. В татарской рекламе отражены национальные ценности, присущие носителям языка и культуры, она учитывает особенности менталитета аудитории, нравственные нормы и убеждения татарской нации. Тексты такого рода часто включают в себя элементы так называемой «национальной идентичности», что выражается в обращении к географическим указаниям, героям татарских сказок и стихов, национальным праздникам и кухне, религиозным обрядам, татарской народной музыке в качестве фона для радиорекламы, а также для продвижения татарских исполнителей с помощью афиш.
\end{abstract}

Ключевые слова: рекламный текст, татарский язык, культурные ценности, национальная идентичность, потребители, продвижение товара. 